\section{International development}

\section{Overseas development assistance}

(Tables 3.1 and 3.2)

The Department for International Development (DFID) is the UK government department with lead responsibility for overseas development. DFID's aim is to eliminate poverty in poorer countries through achievement of the Millennium Development Goals (MDGs) by 2015. Statistics relating to international development are published on a financial year basis and on a calendar year basis. Statistics on a calendar year basis allow comparisons of aid expenditure with other donor countries. Aid flows can be measured before (gross) or after (net) deductions of repayments of principal on past loans. These tables show only the gross figures.

Aid is provided in two main ways: Bilateral funding is provided directly to partner countries while multilateral funding is provided through international organisations.

Funds can only be classified as multilateral if they are channelled through one of the organisations listed in the OECD Development Assistance Committee (DAC) statistical reporting directives which identifies all multilateral organisations. This list also highlights some bodies that might appear to be multilateral but are actually bilateral (in particular this latter category includes some international non-governmental organisations such as the International Committee of the Red Cross and some public-private partnerships such as the Global Alliance for Vaccines and Immunisation). The DAC list of multilaterals is updated annually based on members nominations. Organisations must be engaged in development work to be classified as multilateral aid channels. ${ }^{1}$

While core funding to multilateral organisations is always classified as multilateral expenditure, additional funding channelled through multilaterals is often classified as bilateral expenditure. This would be the case in circumstances where a DFID country office transfers some money to a multilateral organisation (for example, a UN agency) for a particular programme in that country (or region). That is, where DFID has control over what the money is being spent on and/or where it is being spent. Likewise, if DFID responds to an emergency appeal from an agency for a particular country

money may be classified as bilateral while a case is being made for a new multilateral organisation to be recognised. or area, the funds will be allocated as bilateral spend to that country or region. As a result, some organisations, such as UN agencies have some of their DFID funding classified as bilateral and some as multilateral.

DFID is planning to introduce a new activity reporting system between 2007/08 and 2009/10. The new system will integrate all DFID's current financial and project management systems. To coincide with the introduction of the new system, DFID is reviewing how it classifies its aid delivery types. The outcome of this review may lead to the introduction of a new set of classifications which may result in changes to the format in future publications.

Table 3.1 shows the main groups of multilateral agencies; the International Development Association being the largest in the World Bank Group.

Bilateral assistance takes various forms:

Financial aid: Poverty Reduction Budget Support (PRBS) - funds provided to developing countries for them to spend in support of their expenditure programmes whose longterm objective is to reduce poverty. Funds are spent using the overseas governments' own financial management, procurement and accountability systems to increase ownership and long-term sustainability. PRBS can take the form of a general contribution to the overall budget - general budget support - or support with a more restricted focus which is earmarked for a specific sector - sector budget support.

Other financial aid - funding of projects and programmes such as sector-wide programmes not classified as PRBS. Financial aid in its broader sense covers all bilateral aid expenditure other than technical cooperation and administrative costs but in Statistics on International Development (SID) Humanitarian Assistance, DFID Debt Relief, and 'Other bilateral aid' are separately categorised. Aid and Trade Provision which was previously identified in SID has now been merged into 'Other financial aid' as it is a rapidly declining flow.

Technical co-operation - activities designed to enhance the knowledge, intellectual skills, technical expertise or the productive capability of people in recipient countries. It also covers funding of services which contribute to the design or implementation of development projects and programmes.

This assistance is mainly delivered through research and development, the use of consultants, training (generally overseas partners visiting the UK or elsewhere for a training programme) and employment of 'other personnel' (nonDFID experts on fixed-term contracts). This latter category is growing less significant over time as existing contracted staff reach the end of their assignments. 
Other bilateral aid - this category comprises support to the development work of UK and international voluntary organisations, grants to the British Council and for other development work by UK institutions, and non-emergency special appeals through multilateral agencies. The remaining element of 'Other bilateral aid' is made up of a number of categories including, for example, DFID's contributions to two multi-donor trust funds for Sudan, the Development Awareness Fund and the provision of books, equipment and other supplies.

Humanitarian assistance - provides food, aid and other humanitarian assistance including shelter, medical care and advice in emergency situations and their aftermath. Work of the conflict pools is also included.

DFID debt relief - this includes sums for debt relief on DFID aid loans and cancellation of debt under the Commonwealth Debt Initiative (CDI). The non-CDI DFID debt relief is reported on the basis of the 'benefit to the recipient country'. This means that figures shown represent the money available to the country in the year in question that would otherwise have been spent on debt servicing. The CDI debt cancellation is reported on a 'lump sum' basis where all outstanding amounts on a loan are shown at the time the agreement to cancel is made.

CDC investments - CDC Group plc (or CDC) replaced the former Commonwealth Development Corporation in 1999. CDC was founded in 1948 and is now the UK Government's instrument for investing in the private sector in developing economies (it does so through fund management companies, of whom the largest is Actis Capital LLP). CDC has activities in more than 50 developing countries. CDC provides equities an concessional loans to companies in some aid-eligible countries, and these disbursements and repayments are included as UK flows. Although CDC no longer provides loans to governments, it did in the past and these existing loans can become eligible for debt relief.

Non-DFID debt relief - comprises CDC debt and Export Credit Guarantee Department (ECGD) debt. CDC has a portfolio of loans to governments which can become eligible for debt relief under the HIPC (Heavily Indebted Poor Countries) or other debt relief deals. In 2005/06 f90 million of debts owed to CDC were reorganised. ECGD is the UK's official Export Credit Agency which provides insurance for exporters against the main risks in selling overseas and guarantees to banks providing export finance. It also negotiates debt relief arrangements on commercial debt.

Other - This includes contributions from other government departments to civil society organisations, British Council and Global Conflict Pool, and small amounts of drug related assistance funded by the Home Office and the Foreign and Commonwealth Office.

Further details on the UK's development assistance can be found in the Department for International Developments publication Statistics on International Development which can be found on the website at: www.dfid.gov.uk/AboutDFID/Finance-and-performance/DFID-Expenditure-Statistics/. International Comparisons are available in the OECD Development Assistance Committee's annual report. 


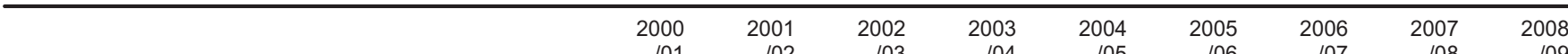

Bilateral Assistance

Department for International Development

Poverty Reduction Budget Support (General) IUJs

Poverty Reduction Budget Support (Sector) I4UJ

Other Financial Aid

Technical Co-operation Projects LUOS

Other Bilateral Aid LUOT

Humanitarian Assistance

DFID Debt Relief

CDC Investments

Debt Relief

LUOT

LUOU

LUOX

$\mathrm{EQ} 4 \mathrm{~B}$

LUOY

Total

LUOZ $\overline{1918441} \overline{2081504} \overline{2540613} \overline{2635081} \overline{3208072} \overline{4569524} \overline{5124083} \overline{3517389} \overline{4333920}$

Multilateral Assistance

European Community ${ }^{2}$

World Bank Group

IMF Poverty Reduction and Growth Facility

Global Environmental Assistance

HIPC Trust Funds

UN Agencies

Regional Development Banks

Other $^{3}$

LUPA $\quad 723651 \quad 744141 \quad 897826108238912220181191961112321512003191407901$

$\begin{array}{llllllllll}\text { LUPB } & 342410 & 173722 & 300021 & 150000 & 150000 & 364909 & 493333 & 493387 & 573652\end{array}$

\begin{tabular}{lrrrrrrr} 
LUPC & - & 11147 & 11434 & 9417 & 1767 & 23728 & 15 \\
\hline & 21144 & 25337 & 27338 & 61213 & 52445 & 53460 & 50260
\end{tabular}

$\begin{array}{llllll}25337 & 27338 & 61213 & 52445 & 53460 & 50260\end{array}$

$\begin{array}{lrrrrrrrr}\mathrm{EQ} 4 \mathrm{D} & 27518 & 23400 & 17855 & 22910 & 42123 & 11094 & 18666 & . .\end{array}$

$\begin{array}{lrrrrrrr}\text { LUPD } & 122423 & 163645 & 176487 & 196406 & 211638 & 252745 & 245019 \\ \text { LUPE } & 54784 & 75383 & 90648 & 80391 & 82166 & 77759 & 123591\end{array}$

$\begin{array}{lllllllllll}\text { LUPF } & 134086 & 111076 & 151473 & 155861 & 164750 & 105891 & 360443 & 256348 & 310659\end{array}$

Total

Administrative costs

LUPG $\overline{1322571} \overline{1192584} \overline{1525807} \overline{1584656} \overline{1748406} \overline{1915506} \overline{2222010} \overline{2246995} \overline{2600365}$

Total Gross Public Expenditure on Aid

$\begin{array}{lllllllllll}\text { LUPH } & 138507 & 132214 & 154127 & 248698 & 227769 & 256451 & 245893 & 262731 & 249000\end{array}$

LUPI $\overline{3379519} \overline{3406301} \overline{4220547} \overline{4468435} \overline{5184247} \overline{6741481} \overline{7591986} \overline{6027115} \overline{7183285}$

1 See chapter text.

2 The institution, not the member states of the European Union.

Source: Department for International Development: 01355843764.

3 IMF Poverty Reduction and Growth Facility, Global Environmental Assis-

tance, HIPC Trust Funds and Regional Development Banks are now includ-

ed in Multilateral Assistance Other.

\section{Total bilateral gross public expenditure on aid (GPEX): by main recipient countries and regions ${ }^{1}$}

United Kingdom

$£$ Thousand

\begin{tabular}{|c|c|c|c|c|c|c|c|c|c|c|}
\hline & & $\begin{array}{r}1999 \\
/ 00\end{array}$ & $\begin{array}{r}2000 \\
/ 01\end{array}$ & $\begin{array}{r}2001 \\
/ 02\end{array}$ & $\begin{array}{r}2002 \\
103\end{array}$ & $\begin{array}{r}2003 \\
104\end{array}$ & $\begin{array}{r}2004 \\
105\end{array}$ & $\begin{array}{r}2005 \\
106\end{array}$ & $\begin{array}{r}2006 \\
/ 07\end{array}$ & $\begin{array}{r}2007 \\
108\end{array}$ \\
\hline \multicolumn{11}{|l|}{ Main recipients } \\
\hline India & LUPJ & 104016 & 126700 & 198576 & 182708 & 242736 & 267510 & 270065 & 293706 & 312751 \\
\hline Afghanistan & $\mathrm{C} 224$ & 5452 & 7465 & 50027 & 76018 & 99595 & 98959 & 126949 & 123011 & 146818 \\
\hline Pakistan & LUPY & 23472 & 15890 & 44838 & 46852 & 66299 & 55277 & 97688 & 118150 & 88145 \\
\hline Cameroon & I53M & 7005 & 5467 & 3652 & 28971 & 7764 & 16547 & 3170 & 115408 & 2013 \\
\hline Tanzania & LUPK & 74709 & 110590 & 203830 & 102614 & 162372 & 130009 & 114134 & 115023 & 125353 \\
\hline Sudan & EU5S & 3189 & 4912 & 5598 & 19222 & 24663 & 83964 & 117114 & 109917 & 138702 \\
\hline Bangladesh & LUPM & 69670 & 75005 & 60375 & 73246 & 155364 & 149152 & 128258 & 109313 & 129725 \\
\hline Serbia & I53N & 6393 & 15670 & 11531 & 305036 & 4795 & 4001 & 48971 & 95713 & 3491 \\
\hline Ethiopia & C225 & 7299 & 16484 & 12088 & 44224 & 43665 & 73044 & 62562 & 90506 & 140011 \\
\hline Malawi & LUPP & 49058 & 54648 & 46651 & 49266 & 54437 & 56429 & 68653 & 88686 & 72619 \\
\hline Ghana & LUPL & 51887 & 74700 & 54479 & 86294 & 73448 & 145835 & 96315 & 93147 & 93076 \\
\hline Congo, Dem Rep & $\mathrm{C} 223$ & 2132 & 6752 & 10262 & 15574 & 151657 & 36585 & 58832 & 79283 & 82910 \\
\hline Uganda & LUPN & 89978 & 98352 & 68091 & 54041 & 59694 & 62928 & 72064 & 79035 & 77231 \\
\hline Iraq & $\mathrm{C} 222$ & 6585 & 9545 & 7760 & 18853 & 214313 & 391507 & 426249 & 71829 & 40649 \\
\hline Kenya & EU5W & 32665 & 62620 & 34227 & 63404 & 28647 & 37824 & 65486 & 67054 & 52135 \\
\hline Indonesia & LUPZ & 58812 & 28405 & 18232 & 42613 & 17449 & 34526 & 58553 & 62290 & 32715 \\
\hline China & LUPS & 26246 & 56740 & 50266 & 44386 & 42406 & 42476 & 36854 & 60086 & 83743 \\
\hline Mozambique & LUPV & 70643 & 43876 & 134133 & 39101 & 36713 & 47941 & 56540 & 56273 & 67799 \\
\hline Total & LUQD & 750261 & 923108 & 1094379 & 1366848 & 1550951 & 1971164 & 3237881 & 3642536 & 1889550 \\
\hline Total other countries & LUQE & 899776 & 837292 & 886021 & 1095698 & 1084130 & 1236908 & 1331643 & 1481547 & 1627839 \\
\hline \multicolumn{11}{|l|}{ Regional totals } \\
\hline Africa & LUQF & 628719 & 774692 & 865317 & 891954 & 1058005 & 1282423 & 2425880 & 3071676 & 1552123 \\
\hline America & LUQG & 237961 & 180165 & 166949 & 221526 & 103358 & 126278 & 85389 & 119491 & 68545 \\
\hline Asia & LUQH & 375839 & 413294 & 534954 & 609138 & 969466 & 1243004 & 1356415 & 1091488 & 1116528 \\
\hline Europe & LUQI & 191697 & 113859 & 97609 & 384240 & 74871 & 62295 & 90086 & 135699 & 39496 \\
\hline Pacific & LUQJ & 7248 & 5029 & 6885 & 5362 & 4484 & 3272 & 3823 & 2670 & 2842 \\
\hline World unallocated $^{2}$ & LUQK & 208574 & 273363 & 308686 & 350327 & 451897 & 490800 & 607931 & 703059 & 737855 \\
\hline Total Bilateral GPEX & LUQL & 1650037 & 1760400 & 1980400 & 2462546 & 2635081 & 3208072 & 4569524 & 5124083 & 3517389 \\
\hline
\end{tabular}

1 See chapter text.

Source: Department for International Development: 01355843764

2 Includes grants to VSO, CSOs, Research Institutions and Commonwealth

Organisations based in the UK. 